Економічні науки: збірник наукових праџь Луцького національного технічного університету. - Серія "Регіональна економіка". - Випуск 15 (59). - Редкол.: відп. ред. д.е.н., професор Л.Л. Ковальська. - Луиьк: ІВВ Луиького НТУ, 2018. - 292 с.

УДК 316.33

Завадська О.М.

к.е.н., старший викладач

Луцький національний технічний університет

\title{
СОЦІАЛЬНИЙ ДІАЛОГ ЯК ОСНОВА РЕФОРМУВАННЯ СОЦІАЛЬНОÏ СФЕРИ В УКРАЇНІ
}

В статті розглянуто проблеми сутності та ролі соціального діалогу як важливого інструменту реформування соціальної сфери. Міжнародний досвід свідчить, що зміни в соціально-трудових відносинах у ХХ ст. в усіх країнах із соціальною ринковою економікою супроводжувались налагодженням соціального діалогу, тому для України це питання є доволі актуальним.

Ключові слова: соціальний діалог, соціальна сфера, соціальна політика, соціальний захист, трудові колективи, реформування соціальної сфери.

\section{Zavadska O. \\ SOCIAL DIALOGUE AS BASIS OF REFORMATION OF SOCIAL SPHERE IN UKRAINE}

The article discusses the problems of the essence and role of social dialogue as an important tool for reforming the social sphere. International experience shows that changes in social and labor relations in the XX century in all countries with a social market economy were accompanied by the establishment of social dialogue, so this question is very relevant for Ukraine.

According to foreign and domestic scientists, the socio-labor sphere and socio-labor relations are experiencing a certain crisis due to globalization processes, the formation of a post-industrial (informational) society. This requires a qualitative reform of the Institute for Social Dialogue, both in the context of expanding the sphere, further institutionalizing social dialogue, broad involvement of civil society institutions, and ensuring the development of social capital as a necessary basis for the growth of its effectiveness. Particularly relevant is the problem of reforming social and labor relations in general and the institute of social dialogue in particular for Ukraine. Only a broad dialogue between government, business, trade unions and the public sector, the growth of trust between government and civil society, both vertically and horizontally, can ensure the implementation of effective reforms, the transition of the domestic economy to European standards and the achievement of sustainable development of Ukrainian society. in general

Key words: social dialogue, social sphere, social politics, social defence, labour collectives, reformations of social sphere. 

університету. - Серія "Регіональна економіка". - Випуск 15 (59). - Редкол.: відп. ред. д.е.н., професор Л.Л. Ковальська. - Луиьк: ІВВ Луиького НТУ, 2018. - 292 с.

\title{
Завадская Е.Н.
}

\section{СОЦИАЛЬНЫЙ ДИАЛОГ КАК ОСНОВА РЕФОРМИРОВАНИЯ СОЦИАЛЬНОЙ СФЕРЫ В УКРАИНЕ}

\begin{abstract}
В статье рассмотрены проблемы сущности и роли социального диалога как важного инструмента реформирования социальной сферы. Международный опыт свидетельствует, что изменения в социально-трудовых отношениях в XX в. во всех странах с социальной рыночной экономикой сопровождались налаживанием социального диалога, поэтому для Украины этот вопрос есть довольно актуальным.

Ключевые слова: социальный диалог, социальная сфера, социальная политика, социальная защита, трудовые коллективы, реформирования социальной сферы.
\end{abstract}

Постановка проблеми у загальному вигляді та їі зв'язок з важливими науковими і практичними завданнями. Розглядаючи сутність соціального діалогу, слід зазначити, що у сучасних умовах кожен громадянин, навіть не усвідомлюючи цього, є його стороною. Саме завдяки соціальному діалогу досягається узгодження політичних та соціально-економічних інтересів різних соціальних груп 3 метою досягнення соціального миру і стабільності у суспільстві. Оптимальний соціальний діалог зміцнює стосунки між його сторонами, завдяки такому діалогу держава може досягати значного прогресу в соціально-економічному розвитку. Здійснення соціально-економічних реформ у сучасному суспільстві також пов'язане 3 загостренням соціальних проблем, що потребує узгодження інтересів різних соціальних груп цивілізованим, безконфліктним шляхом особливо в часи суспільних трансформацій. Важливим елементом $є$ розуміння глибинної природи соціальної кризи, причин, що іiї породжують, суперечностей об'єктивного і суб'єктивного роду, що утворюють внутрішню сутність кризи і одночасно виступають гарантом можливості подолання кризової ситуації, джерелом соціальної надії. Проявляючись з різним ступенем гостроти, вона нерідко набуває характеру соціального конфлікту, тобто 
Економічні науки: збірник наукових праиь Луиького національного технічного університету. - Серія "Регіональна економіка". - Випуск 15 (59). - Редкол.: відп. ред. д.е.н., професор Л.Л. Ковальська. - Луцьк: ІВВ Луиького НТУ, 2018. - 292 с.

«діючої» суперечності, що реалізує себе у зіткненні носіїв цих самих суперечних інтересів, мотивів, бажань та сподівань.

Аналіз останніх досліджень, у яких започатковано вирішення проблеми. Окремі аспекти проблематики становлення та розвитку соціального діалогу в Україні досліджувались в працях таких науковців як: Т. Бабич, Н. Балашов, Н. Громадська, М. Головко, М. Дубровський, В. Жуков, М. Коляда, Н. Крещенко, Ю. Маршавін, Д. Неліпа, Н. Нечитайло, Г. Осовий, В. Пилипенко, Ю. Привалов, Г. Чанишева, В. Цвих та ін. Водночас науковцями та експертами недостатньо акцентується увага на змінах цього інституту в умовах глобальних трансформацій, що в кінцевому рахунку впливає на процес його інституалізації та ефективності функціонування на національних рівнях.

Цілі статті. У статті досліджено сутність процесів соціального діалогу та соціального конфлікту як актуальних чинників реформування соціальної сфери в Україні.

Виклад основного матеріалу дослідження 3 обгрунтуванням отриманих наукових результатів. Соціальний діалог як процес представляє собою взаємовідносини між трудовими колективами та роботодавцями, включаючи інші суб'єкти, такі як державні органи, міжнародні організації тощо. Але основними суб'єктами, що ініціюють процес соціального діалогу є трудові колективи.

Трудові колективи залишаються більш-менш стійкими утвореннями, які характеризуються єдністю волі, мети i інтересів. У складі трудового колективу працівники реалізують колективні трудові права. Державно-правове оформлення волі трудового колективу у вигляді рішення загальних зборів (конференції) необхідне при встановленні і зміні колективних умов праці, укладенні колективного договору, затвердженні правил внутрішнього трудового розпорядку, вирішенні колективних трудових спорів та в інших випадках здійснення трудовим колективом повноважень, передбачених законодавством. 
Економічні науки: збірник наукових праџь Луцького національного технічного університету. - Серія "Регіональна економіка". - Випуск 15 (59). - Редкол.: відп. ред. д.е.н., професор Л.Л. Ковальська. - Луцьк: ІВВ Луиького НТУ, 2018. - 292 с.

Кожна із сторін колективних трудових правовідносин має своїх представників, які є суб'єктами цих відносин. Слід не відокремлювати відносини представництва від колективних трудових відносин, вважаючи, що ті з колективних трудових правовідносин, суб'єктами яких виступають профспілки (їх об'єднання), інші представники працівників, організації роботодавців (їх об'єднання), вже є представницькими за своїм характером. Представництво у колективних трудових правовідносинах відбувається на підставі закону, внутрішнього правового акту організації, рішення профспілкового органу [2].

Соціальний діалог включає всі типи переговорів, консультацій та обміну інформацією між роботодавцями, працівниками та державою, спрямований на успішне вирішення питань соціально-економічної політики [2].

Зміст соціального діалогу на національному рівні, перш за все, визначається реаліями соціально-економічного життя і тому може бути різним залежно від потреб суспільства на різних етапах розвитку, проте часто він повинен реагувати на термінові події. В Україні, згідно з Законом «Про соціальний діалог в Україні» [1, с. 2], передбачено формування порядку утворення, склад та організацію роботи Національної тристоронньої соціально-економічної ради та територіальних соціальноекономічних рад у регіонах. Однією 3 їх характеристик $\epsilon$ розвиток демократії в основних сферах соціально-економічного життя держави, систематична участь громадян у розробці пріоритетних для регіону рішень та контроль за їх реалізацією у важливих, з погляду інтересів громадян, напрямах діяльності.

Отже, соціальний діалог - це процес, що виражається у реалізації колективних переговорів; колективних угод i колективних договорів; участь працівників та їх представників в управлінні організацією; взаємні консультації та інформування сторін соціального діалогу; пошук компромісних рішеннь колективних трудових спорів (конфліктів) [3].

Змін потребує вся система соціального захисту. Враховуючи, що забезпечення соціальних гарантій неможливо без податків, які збираються з бізнесу та населення, важливим 
Економічні науки: збірник наукових праиь Луиького національного технічного університету. - Серія "Регіональна економіка". - Випуск 15 (59). - Редкол.: відп. ред. д.е.н., професор Л.Л. Ковальська. - Луцьк: ІВВ Луцького НТУ, 2018. - 292 с.

елементом реформи соціальної сфери стає забезпечення ефективного соціального діалогу між роботодавцями профспілками та організаціями громадянського суспільства. Тільки об'єднання питань реформи системи соціального захисту i соціального діалогу дасть необхідний ефект i допоможе зберегти людський капітал, який в умовах радикальних ліберальних реформ, може бути знищеним.

Слід підкреслити необхідність розробки стратегії реформування механізму соціального діалогу 3 залученням представників сторін соціального діалогу та експертів організацій громадянського суспільства, розробки стратегії реформування механізму соціального діалогу, як політичного документа та подальшого його адвокатування $[4,5]$.

Отже, слід створити ефективну систему соціального захисту, яка відповідає можливостям держави та запровадити альтернативні державні джерела фінансування системи соціального захисту.

Виникає нагальна потреба в розвитку механізмів соціального інвестування на місцевому рівні, залучення ресурсів 3 різних джерел та забезпечення ефективності використання бюджетних коштів.

Висновки. Отже, соціальний діалог є одним з ефективних механізмів узгодження соціально-економічних інтересів різних соціальних груп i владних структур 3 метою досягнення соціальної злагоди, миру і спокою у суспільстві. Враховуючи, що функції соціальної політики пов'язані 3 узгодженням інтересів певних соціальних груп, оптимальним розв'язанням суспільних суперечностей, гармонізацією інтересів різних верств населення, створенням умов для суспільної злагоди, соціальний діалог здатний виступати досить досконалим інструментом впровадження цієї політики. Він сприяє досягненню соціального миру та злагоди, що $\epsilon$ важливою умовою забезпечення соціальної та політичної стабільності у суспільстві. Соціальний діалог $є$ одним із головних факторів розвитку громадянського суспільства та реформування соціальної сфери України. 
Економічні науки: збірник наукових праць Луиького національного технічного університету. - Серія "Регіональна економіка". - Випуск 15 (59). - Редкол.: відп. ред. д.е.н., професор Л.Л. Ковальська. - Луцьк: ІВВ Луиького НТУ, 2018. - 292 с.

1. Закон України «Про соціальний діалог в Україні» - Відомості Верховної Ради України (ВВР), 2011. - № 28, - с. 255.

2. Про розвиток соціального діалогу в Україні: Указ Президента України від 29.12.05 № 1871/2005 // Урядовий кур'єр. - 2006. - 25 січня.

3. Рихлі Л., Прітцер Р. Соціальний діалог на національному рівні у країнах - кандидатах на вступ до Свропейського Союзу // Соціальне партнерство - шлях до злагоди. - К., 2003. - С. 104-136.

4. Закон України «Про організації роботодавців, ї права та гарантії діяльності» від 20.04.2014 р. - [Електронний ресурс]. - Режим доступу: www.rada.gov.ua 3.

5. Закон України «Про професійні спілки, їх права та гарантії діяльності» від 12.12.2012 р. - [Електронний ресурс]. - Режим доступу: www.rada.gov.ua 